\title{
Prevalence assessment of ectoparasitic arthropods among commonly consumed wildlife in Nsukka, southeast Nigeria
}

\author{
Kingsley Uchenna Ozioko ${ }^{1 *} \mathbb{D}$, Chris Ikem Okoye ${ }^{1}$, Patience Obiageli Ubachukwu', Raymond Awudu Agbu², \\ Bede Izuchukwu Ezewudo ${ }^{1}$ and Celestine Osita Ezea $^{3}$
}

\begin{abstract}
Background: Wildlife reservoirs not only act as a source of infection for vectors but also serve as hosts for the vectors themselves, supporting their populations. Their public health significance in developing countries is of growing importance as a result of zoonotic and enzootic diseases associated with the pathogens they transmit. Therefore, a study was carried out to determine the prevalence of ectoparasites of wild game in Nsukka, southeast Nigeria. Physical examinations were carried out on 143 wildlife, and laboratory identification was employed on the ectoparasites. The collected ectoparasites were identified in the laboratory using literature and with the help of a taxonomist.

Results: Out of the 143 game examined, 114 was infected with at least one parasite representing about $98.6 \%$ of an infestation. Among the parasites identified, Amblyomma spp. showed the highest prevalence of $24.5 \%$ at $95 \%$ confidential intervals of $\mathrm{Cl}(1.45-3.19)-24.5 \%$ ( $p \leq 0.05)$. No difference was observed in the prevalence of the ectoparasites according to sex, except for Ixodes holocyclus. Similarly, no difference was observed in prevalence with reference to age except for Rhipicephalus spp. and Polyplax spinulosa which showed differences.

Conclusions: The present study provides basic data about the most prevalent ectoparasitic arthropod among game in Nsukka, southeast Nigeria, which requires an evaluation of its zoonotic control measures. This work can elicit the risk of possible transmission of some zoonotic and enzootic diseases via game. Improving awareness among local people and bushmeat dealers about the risk of contracting a vector-borne disease through wildlife is crucial.
\end{abstract}

Keywords: Ectoparasites infestation, Nigeria, Prevalence, Wildlife

\section{Background}

Human beings interact with wildlife in their daily lives, both at home and when away from home (CDC 2017), especially at a zoo or during outdoor recreational activities (Ozioko et al. 2018). There is much commonly consumed wildlife referred to as bushmeat or game in the tropics. Bushmeat or game is an important protein source and also a reservoir host of pathogens capable of causing diseases in man (CDC 2017). They host

\footnotetext{
*Correspondence: ukingsley82@yahoo.com

${ }^{1}$ Department of Zoology and Environmental Biology, University

of Nigeria, Nsukka, Nigeria

Full list of author information is available at the end of the article
}

several arthropods which are major vectors of zoonotic and enzootic diseases thereby playing an essential role in the transmission of pathogens to humans and other animals. Wild animals appear to be capable of living with a high parasite load and remain asymptomatic, without any apparent ill-effects on their health. Many of them create undesirable dermal immune responses while acting as vectors of bacteria, viruses, cestodes, nematodes and other disease agents (Wei et al. 2010). Most of the emerging zoonotic diseases are from viral origin and are transmitted by vectors (Taylor et al. 2001) and for the most part are transmitted by wildlife (Woolhouse and Gowtage-Sequeria 2005; Wang and Crameri, 2014). Transmission of the wildlife pathogens 
to humans is a rare event but, once it has happened, human-to-human transmission maintains the infection for a while. It is important to note that hunting wildlife for food and sale increases human-animal contact, with serious zoonotic implications. People who trap, transport, trade, handle and consume wild game risk contracting a bevy of viruses, parasites and other disease-causing organisms carried by wild animals, such as Ebola, yellow fever and HIV (Premaalatha et al. 2017). Recurrent fire outbreaks have resulted in the escape of wildlife into nearby communities. Their sudden relocation poses a threat to human and domestic animals. Besides, the possibility of transferring ectoparasites from wildlife to domestic animals that lack immunity to resist it invariably spread infections to humans as well. Exposure to zoonotic diseases carried by wildlife and their parasites represents a growing threat to public health (AWI 2014). Ectoparasites such as ticks, lice, fleas and mites have been incriminated in the mechanical transmission of pathogens to humans while sucking blood (Omudua and Amuta 2007). Some known common human diseases transmitted by arthropod vectors are epidemic typhus and epidemic relapsing fever (body lice) plague and murine typhus (certain fleas) lyme disease, scrub typhus (biting mites), relapsing fever and many viral diseases (ticks). They parasitize their hosts, damaging their skin and causing irritation to them. Sustainable control of zoonotic diseases requires adequate and useful information on the local and regional distribution of appropriate environmental risk factors (Sowemimo and Asaolu 2008) which are essential for designing and maintaining surveillance strategies (Webber 2015). This information is, however, scarce in West African countries (Onyenwe and Ikpegbu 2004), especially in Nigeria. Besides, studies carried out in specified communities provide limited information in relevance to regional-level control programmes. Even though several studies have been conducted on ectoparasites of animals in some parts of Nigeria, most have been directed only to domestic animals. Therefore, this study was designed to determine the distribution of wildlife arthropods and estimate the infestation parameters of ticks, fleas, mites and lice associated with commonly consumed wildlife in study area. Understanding the richness of ectoparasite species is very crucial as it provides valuable insights into disease transmission and the ecological roles they play in the regulation of their host populations and communities (Wei et al. 2010). Additionally, research on the distribution of wildlife ectoparasite should be carried out to discover what species occur in a particular area, where they are found, and with what hosts they are associated.

\section{Methods}

The study was carried out over a period of one year in different localities within Nsukka, southeast Nigeria (longitude $7^{\circ} 08^{\prime}$ and $7^{\circ} 20^{\prime}$ East and latitude $6^{\circ} 46^{\prime}$ and $6^{\circ} 49^{\prime}$ North). Though the influence of human-induced environmental factors over a long period has made the place almost lose its rain forest features (Igbozuruike 1978), the area has remained an important refuge for over 200 species of wildlife. Some regions in the area are considered to be a grazing area for nomadic herdsmen. There are patches of forests around the valleys of some parched streams, springs and rivers. The area is characterised by tall trees and grassland vegetation where wildlife is widely distributed. Despite considerable national and international laws regulating wildlife conservation in Nigeria, only park and reserves are fully restricted from human activities such as hunting, animal grazing and bush burning.

\section{Sample collection}

The sampled animals consist of Xenus erythropus (16), Thryonomys swinderianus (16), Varanus exanthematicus (17), Sylvicapra grimmia (15), Philantomba maxwellii (15), Numida meleagris (16), Francolinus bicalcaratus (17), Oryctolagus cuniculus (15) and Varanus ornatus (16) (Fig. 1). They were procured directly from hunters who obtained them from their natural habitats for trade and consumption. The animals were caught using various methods such as trapping, use of dogs and shooting. Procured animals were not euthanised and each of them was returned to the owner after ectoparasites were isolated. The ectoparasites were collected with the use of a fine comb, hand lens and a pair of forceps and preserved in labelled vials containing $10 \%$ formalin. Ticks were identified using a stereo microscope, and other parasites were identified using a compound microscope. The parasites were identified using a standard parasitological method for ticks (Soulsby 1982; Walker et al. 2018) lice, fleas and mites (Urquhart et al. 1996; Foreyt 2001).

\section{Statistical analysis}

The analysis was done using SPSS (version 20.0) statistical software and Quantitative Parasitology (version 3.0). The prevalence of parasites was determined using Chi-square test from the contingency tables, while Fisher's exact test was used to calculate the significant difference in prevalence of age, sex and season. The significant difference was set at $(p \leq 0.05)$. 


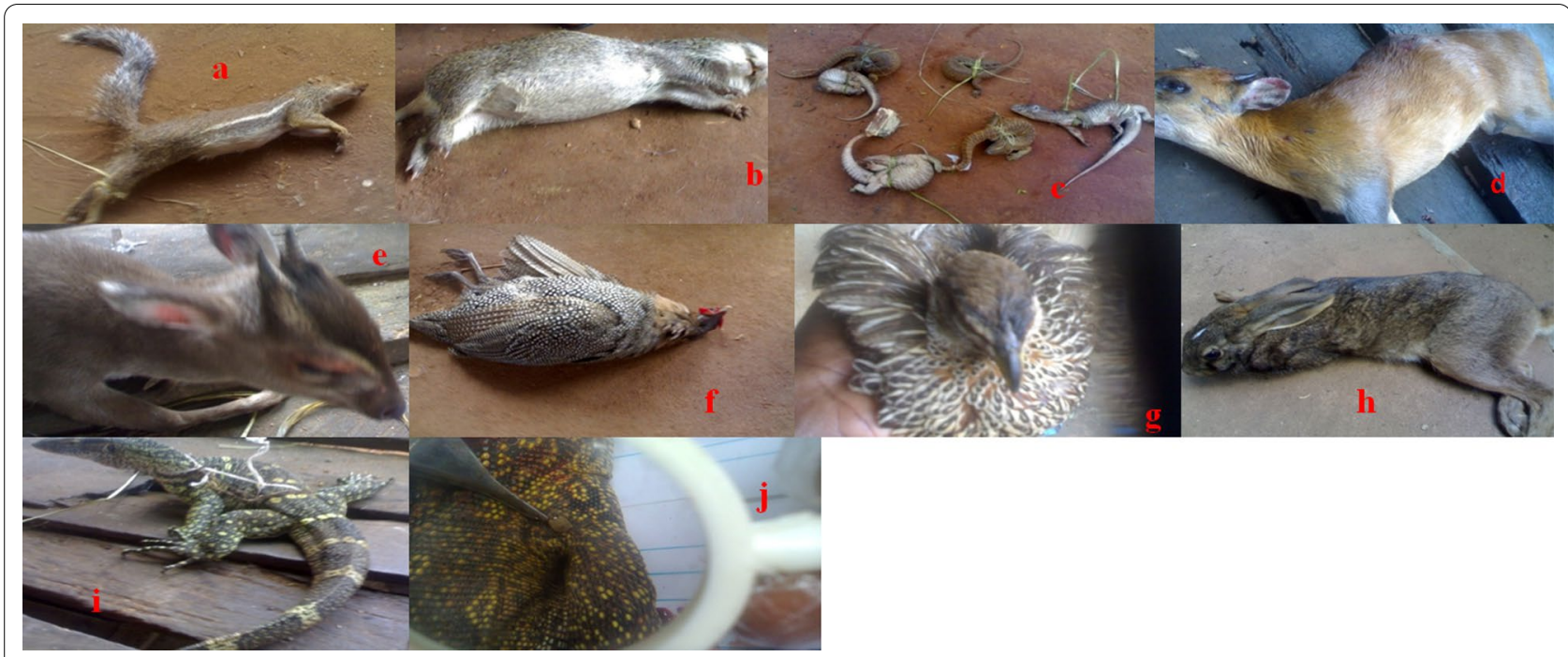

Fig. 1 Samples game animals

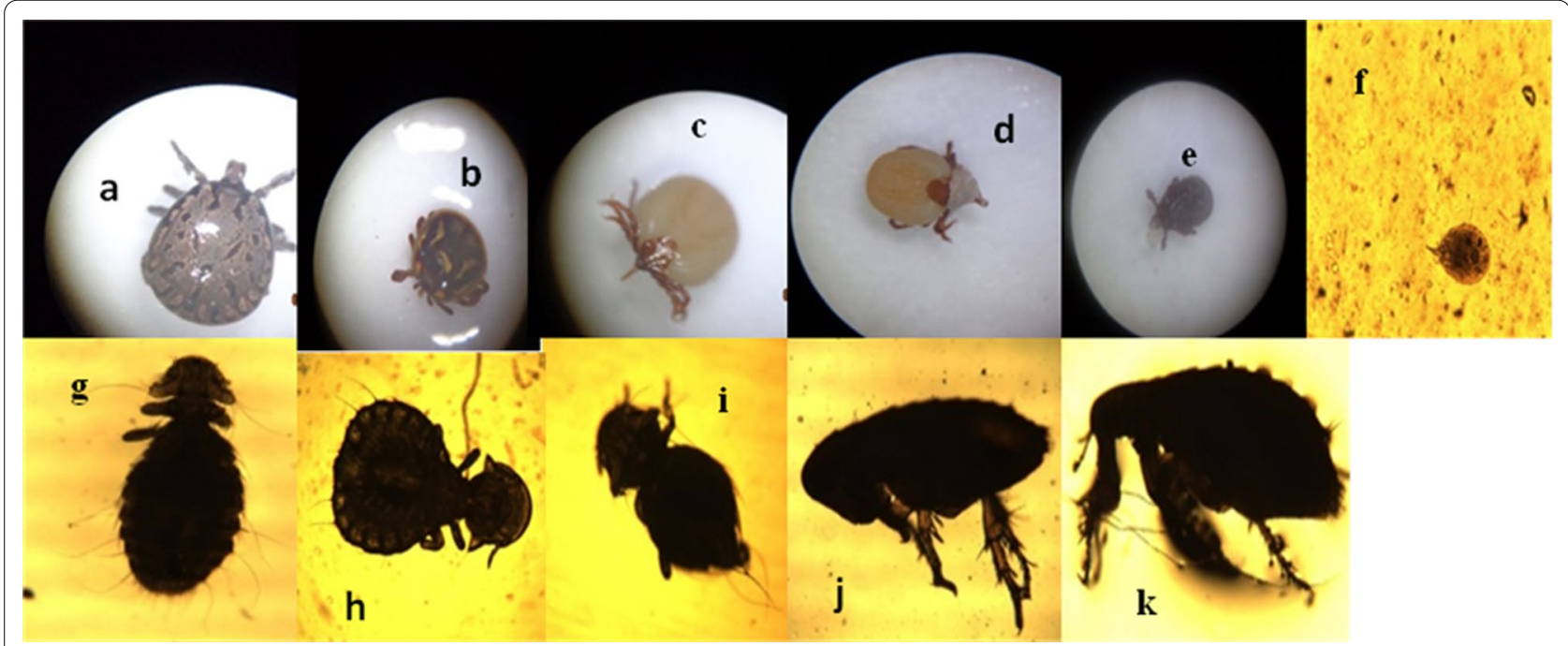

Fig. 2 Ectoparasites found from game animals. $\mathbf{j}-\mathbf{k}=\times 400 ; \mathbf{f}=\times 1000 ; \mathbf{a}-\mathbf{e}=\times 10$

\section{Results}

A total of 3 lice, 5 ticks, 2 fleas and 1 mite belonging to eleven genera were collected (Fig. 2) from 114 samples belonging to the nine examined wildlife species. The most prevalent with a wide range of hosts was Amblyomma spp., which was recorded in three different host species with an overall ectoparasites prevalence of 24.5\% (Table 1). The lowest ectoparasite prevalence was recorded for Dermanyssus gallinae (3.3\%) and was recovered from birds only $(p \leq 0.05)$. Xenopsylla cheopis had the highest prevalence among fleas that were identified, while Polyplax spinulosa had the highest overall prevalence among lice. Ticks (Amblyomma spp.) were collected from three host species ( $N$. meleagris $V$. ornatus, V. exanthimaticus), while Ixodes holocyclus, Dermacentor variabilis and Rhipicephalus spp. were each collected from two host species (F. bicalcaratus, T. swinderianus), (X. erythropus, T. swinderianus) and (O. cuniculus, P. maxwellii), respectively, whereas Boophilus decoloratus were collected from one host species (S. grimmia)) (Table 2). Sucking lice (P. spinulosa) were also collected from small mammals (T. swinderianus, $X$. erythropus and O. cuniculus), while the other two sucking lice, Bovicola spp. and Goniocotes spp., were each collected from ungulate ( $P$. maxwellii, S. grimmia) and aves (F. bicalcaratus), respectively. Reptiles 
Table 1 Overall prevalence of ectoparasites recovered in Nsukka, southeast Nigeria

\begin{tabular}{lcc}
\hline Ectoparasites & Prevalence & N \\
\hline Ticks & $24.5(18.03-32.13)$ & 3 \\
Amblyomma spp. & $6.3(3.19-11.45)$ & 1 \\
Boophilus decoloratus & $4.9(2.32-9.70)$ & 2 \\
Dermacentor variabilis & $10.5(6.15-16.69)$ & 2 \\
Ixodes holocyclus & $8.4(4.79-14.23)$ & 2 \\
Rhipicephalus spp. & & \\
Fleas & $7.7(4.03-13.20$ & 1 \\
Xenopsylla cheopis & $4.9(2.32-7.70)$ & 1 \\
Spilopsyllus cuniculi & & 2 \\
Lice & $14.0(8.98-20.57)$ & 1 \\
Polyplax spinulosa & $11.9(7.25-18.44)$ & \\
Bovicola spp. & $5.6(2.63-10.73)$ & 2 \\
Goniocotes spp. & & \\
Mites & $3.5(1.39-7.93)$ & \\
Dermanyssus gallinae &
\end{tabular}

$N=$ the no of host species; values are presented as infected ( $95 \%$ confidence limit)

were seen parasitized by one ectoparasite, whereas the remaining seven host species were each infested by at least two species of ectoparasites. There was significant $(p \leq 0.05)$ prevalence percentage between or among the various wildlife host species that harbour the same ectoparasites. Fleas (Goniocotes spp.) were seen with lower prevalence and with less range of hosts. The prevalence of Amblyomma spp. infestation was significantly higher in $V$. orantus and $V$. exanthematicus $(100 \%)$ when compared with that of $N$. meleagris $(12.5 \%)$. There was significantly higher prevalence of D. variabilis infestation in X. erythropus (25\%) than in T. swinderianus (18.8\%). The prevalence of $I$. holocyclus was significantly higher in F bicalcaratus (58.8\%) than in T. swinderianus $(37.5 \%)(p \leq 0.05)$, whereas $O$. cuniculus (46.7\%) had significantly higher prevalence of Rhipicephalus spp. than in T. swinderianus (40\%). In wild game infected with $P$. spinulosa, the prevalence of infection was highest in O. cuniculus (86.7\%) followed by $X$. erythropus (25\%) and least in T. swinderianus $(18.8 \%)(p \leq 0.05)$. S. grimmia had a significantly higher prevalence of infestation of Bovicola spp. than $P$. maxwellii. The prevalence of $D$. gallinae infestation was significantly higher in F. bicalcaratus (17.6\%) than in $N$. Melagris (12.5\%). The prevalence of infection between season, sex and age among the wild game is presented in (Table 3). The prevalence of Rhipicephalus spp., Spilopsyllus cuniculi, Bovicola spp. and D. gallinae in the wild game was more in the dry season than in the rainy season, while the prevalence of Amblyomma spp., Boophilus spp., D. variabilis, $X$. cheopis and $P$. spinulosa was more in the rainy season. However, there was no seasonal difference $(p>0.05)$ in the prevalence of the parasites. There was no sex difference in the prevalence of the parasites, except I. holocyclus which significantly

Table 2 Prevalence rate of ectoparasites infestation among different wildlife

\begin{tabular}{|c|c|c|c|c|c|c|c|c|c|c|}
\hline \multirow[t]{2}{*}{ Bushmeat sampled } & \multicolumn{2}{|l|}{ Aves } & \multicolumn{2}{|l|}{ Reptiles } & \multicolumn{3}{|c|}{ Small mammals } & \multicolumn{2}{|c|}{ Ungulates } & \multirow[t]{2}{*}{$x^{2}$} \\
\hline & F. $b$ & N. $m$ & V.o & V.e & T.S & $X . e$ & O. $c$ & P. $m$ & S. $g$ & \\
\hline$N$ & 17 & 16 & 16 & 17 & 16 & 16 & 15 & 15 & 15 & \\
\hline \multicolumn{11}{|l|}{ Ticks } \\
\hline Amblyommaspp. & - & $2(12.5)$ & $16(100)$ & $17(100)$ & - & - & - & - & - & $133.53^{*}$ \\
\hline Boophilus decoloratus & - & - & - & - & - & - & - & - & $9(60.0)$ & - \\
\hline Dermacentor variabilis & - & - & - & - & $3(18.8)$ & $4(25.0)$ & - & - & - & $26.20^{*}$ \\
\hline Ixodes holocyclus & $10(58.8)$ & - & - & - & $6(37.5)$ & - & - & - & - & $63.82^{*}$ \\
\hline Rhipicephalus spp. & - & - & - & - & - & - & $7(46.7)$ & $6(40.0)$ & - & $54.26^{*}$ \\
\hline \multicolumn{11}{|l|}{ Fleas } \\
\hline Xenopsylla cheopis & - & - & - & - & - & - & - & - & $11(73.3)$ & - \\
\hline Spilopsyllus cuniculi & - & - & - & & & - & $7(46.7)$ & - & - & - \\
\hline \multicolumn{11}{|l|}{ Lice } \\
\hline Polyplax spinulosa & - & - & - & - & $3(18.8)$ & $4(25.0)$ & $13(86.7)$ & - & - & $83.39^{*}$ \\
\hline Bovicola spp. & - & - & & - & - & - & - & $6(40.0)$ & $11(73.3)$ & $80.00^{*}$ \\
\hline Goniocotes spp. & $8(47.1)$ & - & - & - & - & - & - & - & - & - \\
\hline \multicolumn{11}{|l|}{ Mites } \\
\hline Dermanyssus gallinae & $3(17.6)$ & $2(12.5)$ & - & - & - & - & - & - & - & $17.98^{*}$ \\
\hline
\end{tabular}

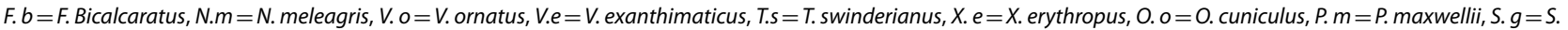
grimmia, $N=$ number of bushmeat sampled; values are presented as infected $(\%), X^{2}=$ Chi-square test, ${ }^{*} p \leq 0.05$ 
Table 3 Prevalence rate of ectoparasites infestation based on season, sex and age

\begin{tabular}{|c|c|c|c|c|c|c|c|c|c|}
\hline \multirow[t]{2}{*}{ Parasite recovered } & \multicolumn{3}{|l|}{ Season } & \multicolumn{3}{|l|}{ Sex } & \multicolumn{3}{|l|}{ Age } \\
\hline & Dry & Rainy & $\mathrm{s}$ & Male & Female & $\mathrm{S}$ & Juvenile & Adult & $S$ \\
\hline$N$ & 17 & 16 & & 16 & 17 & & 16 & 16 & \\
\hline \multicolumn{10}{|l|}{ Ticks } \\
\hline Amblyomma spp. & $17(21.5)$ & $18(28.1)$ & 0.361 & $15(21.4)$ & $20(27.4)$ & 0.407 & $16(23.5)$ & $19(25.3)$ & 0.8 \\
\hline Boophilus decoloratus & $4(5.1)$ & $5(7.8)$ & 0.501 & $4(5.7)$ & $5(6.8)$ & 0.78 & $2(2.9)$ & $7(9.3)$ & 0.11 \\
\hline Dermacentor variabilis & $3(3.8)$ & $4(6.2)$ & 0.499 & $4(5.7)$ & $3(4.1)$ & 0.65 & $1(1.5)$ & $6(8.0)$ & $0.07^{*}$ \\
\hline Ixodes holocyclus & $8(10.1)$ & $8(12.5)$ & 0.654 & $12(17.1)$ & $4(5.5)$ & $0.02^{*}$ & $8(11.8)$ & $8(10.7)$ & 0.83 \\
\hline Rhipicephalus spp. & $7(8.9)$ & $6(9.4)$ & 0.915 & $8(11.4)$ & $5(6.8)$ & 0.34 & $1(1.5)$ & $12(16.0)$ & $0.03^{*}$ \\
\hline \multicolumn{10}{|l|}{ Fleas } \\
\hline Xenopsylla cheopis & $6(7.6)$ & $5(7.8)$ & 0.961 & $6(7.6)$ & $5(7.8)$ & 0.961 & $4(5.9)$ & $7(9.3)$ & 0.43 \\
\hline Spilopsyllus cuniculi & $4(5.1)$ & $3(4.7)$ & 0.918 & $3(4.3)$ & $4(5.5)$ & 0.741 & $0(0)$ & $7(9.3)$ & $0.01 *$ \\
\hline \multicolumn{10}{|l|}{ Lice } \\
\hline Polyplax spinulosa & $8(10.1)$ & $12(18.8)$ & 0.139 & $8(11.4)$ & $12(16.4)$ & 0.38 & $6(8.8)$ & 14 (18.7) & $0.09^{*}$ \\
\hline Bovicola spp. & $9(11.4)$ & $8(12.7)$ & 0.812 & $10(14.3)$ & $7(9.7)$ & 0.402 & $5(7.5)$ & $12(16.0)$ & 0.11 \\
\hline Goniocotes spp. & $9(11.4$ & $12(18.8)$ & 0.299 & $5(7.1)$ & $3(4.1)$ & 0.43 & $3(4.4)$ & $5(6.7)$ & 0.55 \\
\hline \multicolumn{10}{|l|}{ Mites } \\
\hline Dermanyssus gallinae & $3(3.8)$ & $2(3.1)$ & 0.828 & $4(5.7)$ & $1(3.5)$ & 0.15 & $2(2.9)$ & $3(4.0)$ & 0.73 \\
\hline
\end{tabular}

The comparison is between season (dry and rainy), sex (male and female) and age (juvenile and adult) $N=$ number of bushmeat sampled; values are presented as infected (\%), $\mathrm{S}=$ significance, ${ }^{*} p \leq 0.05$

differed $(p \leq 0.05)$ between the male and female. All species of parasites recovered from the wild showed higher prevalence in adults than in juvenile and did not differ significantly $(p>0.05)$ except Rhipicephalus spp. and $P$. spinulosa which significantly differed $(p \leq 0.05)$.

\section{Discussion}

The present finding revealed that animals from the wild are heavily infested with ectoparasites that can be transmitted to their offsprings and other mammals, including humans. The parasites encountered in this study have been reported previously from wildlife elsewhere (Mbaya et al. 2008; Parola et al. 2013; Atuman et al. 2019). Many ectoparasites that are vectors of zoonotic diseases live in close association with their animal hosts in a stable habitat and equilibrium with the climate and soil, undisturbed by humans. The present study has shown that any shift in this equilibrium due to the pressure of human activities portends a great danger of zoonotic pathogens being transmitted to humans and their domesticated animals through these parasites. To the best of our knowledge, parasitic tick, Amblyomma spp. found on the lizards, V. orantus and $V$. exanthematicus is the first record on lizard hosts in the study area. The result also shows that the tick, Amblyomma spp., is the most dominant ectoparasite in the wild game studied and mostly recovered from lizards. Amblyomma spp. and Boophilus decoloratus are vectors of tick-borneAfrican fever also known as Rickettsia africae. Rickettsioses are emerging and re-emerging vector-borne global diseases with zoonotic importance (Omitola and Taylor-Robinson 2020). I. holocyclus was the second abundant tick isolated. I. holocyclus can cause subsequent mortality and paralysis among domestic and wild animals. I. holocyclus can act as a vector of ehrlichiosis, lyme disease, spotted fever and babesiosis and transmit the disease to man, carnivores and ruminants. The low incidence of some ectoparasites found in this study could be due to the grooming behaviour of animals where one licks the other. Animals have particular grooming habits that often involve licking the fur, and while they lick one another, it brings them into proximity and therefore increases the risk of transmitting parasites with a direct life cycle (Gillespie 2006); besides, many ectoparasites are the intermediate host for intestinal parasites, and therefore, the animals may become infected via the ingestion of these hosts. The recovery of only a few mites (D. gallinae) from the whole animals examined during the present investigation probably indicates that the study area represents a marginal distribution area for mite. The lowest prevalence of Dermamyssus spp. encountered in this work is in line with the work of Swai et al. (2010) who also recorded its least prevalence while working with ectoparasites and blood parasites of free-range fowls of Northern Tanzania. Dermanyssus mites are blood feeders and are responsible for anaemia, welfare problems 
in birds and dermatitis in humans. They can act as vectors for some bacteria such as Salmonella, Spirocheta and Rickettsia (Devos and Lambrechts 2003). X. cheopis also identified can also serve as an intermediate host for Hymenolepis nana and Hymenolepis diminuta (Mathison and Prittb 2014). Sex-related differences in parasite prevalence are commonly observed where the males exhibit higher parasitism than the females. The difference in sex prevalence may be attributed to different factors influencing a host at the same time such as exposure differences and mating behaviours. There is a noticeable disparity in infection prevalence among the various age range studied which can be attributed to the varying degree of exposure to the infection. Juveniles with lower acquired resistance unlike adults have never lived in the wild nor have they been exposed (Wakelin 1996). Moreover, animal hosts can regulate the severity of the infection by developing acquired resistance to the parasites. The higher prevalence of ectoparasites observed in older animals may be due to the longer period of exposure to parasitic infestation. Higher prevalence of the ectoparasites was observed in rainy season than in dry season, which is in line with the report of Devos and Lambrechts (2003). According to their report, most parasites tend to reach their highest biotic potential during the rainy season, while those with statistically higher in the dry season probably indicate the survivors from infections acquired during the late rainy season. No significant seasonal difference was observed on the prevalence of the ectoparasites. Variation in exposure to ectoparasites infection of animals can influence their distribution and prevalence patterns. The fact that most of the bushmeat animals examined during this study have been residents in the same ecological zone for a long time may explain the finding of similar parasite in different animal types. Many of these animals share many things in common and thus could easily transfer infection among themselves. The infestations might be explained by these animals' shelter and social behaviour. Some of the parasites identified in this study have been reported on cattle owned by Fulani pastoralists and other livestock in the study area (James-Rugu and Iwuala 2002; Tongjura et al. 2012; Adebayo et al. 2018). Whether some of the parasites were transmitted to domestic from the wildlife or are natural to the area is unknown, but it must be kept in mind that humans travel to import exotic animal denote that parasites harboured do not necessarily come from a targeted area. They may have been introduced into the study area through any of the numerous species of exotic animal now living free in the area. Domestic and wild animal hosts encroach into each other territories thereby promoting the spread of zoonotic or enzootic transmission of certain agents.

\section{Conclusions}

The study has documented the common ectoparasite infesting wild game and could also provide an insight into the common ectoparasite of wildlife at large. The prevalence of ectoparasite infections in the wildlife population in this study is of public health significance which could be a threat to humans and their domestic animals. To the best of our knowledge, no significant attention has been given to control ectoparasites of wildlife in the study area, despite the threat of these organisms to man and their domestic animals. Therefore, both wildlife and domestic animal vector control programs must be carried out at the same time to prevent the spread of zoonotic diseases. However, additional research is needed to further investigate the wildlife ectoparasites infestations and their role in the transmission of diseases in the studied area.

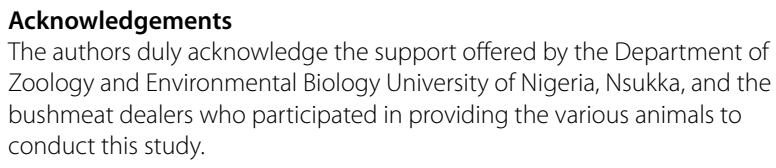

\section{Authors' contributions}

$\mathrm{CIO}$ supervised and directed the survey. KUO, BIE, COE and RAA collected and carried out the identification and processing of the ectoparasites. $\mathrm{ClO}$ and

$\mathrm{KUO}$ analysed and discussed the results. KUO wrote the first draft of the manuscript, while POU and KUO revised and reviewed it for publication. All authors read and approved the final manuscript.

\section{Funding}

Not applicable.

\section{Availability of data and materials}

The datasets analysed during the current study are available from the corresponding author on reasonable request.

\section{Ethics approval and consent to participate}

The study was approved by the Zoology and Environmental Biology Postgraduate Board (UNN) in line with the Ethical Committee and the International Guidelines for Handling of Animals (UNN research policy November, 2013).

\section{Consent for publication}

Not applicable.

\section{Competing interests}

The authors declare that they have no competing interests.

\section{Author details}

${ }^{1}$ Department of Zoology and Environmental Biology, University of Nigeria, Nsukka, Nigeria. ${ }^{2}$ Central Laboratory Unit, Federal University Wukari, Taraba State, P. M. B. 1020, Wukari, Nigeria. ${ }^{3}$ Department of Biology, Federal University of Technology, Imo State, Owerre, Nigeria.

Received: 28 August 2020 Accepted: 2 December 2020

Published online: 06 January 2021 


\section{References}

Adebayo FO, Adamu MO, Onawo AS (2018) An investigation of the ectoparasites of slaughtered cattle at Keffi abattoir in Nassarawa State of Nigeria, sub-Sahara. Africa Int J Animal Sci Technol 2(1):18-22

Atuman YJ, Kudi CA, Abdu P, Okubanjo OO, Abubakar A (2019) Prevalence of parasites of wildlife in Yankari game reserve and Sumu wildlife park in Bauchi State. Nigeria Sokoto J Vet Sci 17(4):70-79

AWI (Animal Welfare Institute) (2014) bushmeat. www.awionline.org/ealert. Accessed 29th Dec 2018

CDC (Centers for Disease Control) (2017) https://www.cdc.gov/onehealth/ basics/zoonotic-diseases.html. Accessed 17th Mar 2019

Devos V, Lambrechts MC (2003) Emerging aspect of wildlife diseases in Southern Africa. In: Proceeding of sarcus symposium on nature conservation as a farmland. Gorongosa Natural Park, Mozambique, pp 97-99

Foreyt WJ (2001) veterinary parasitology: reference manual, 3rd edn. lowa State University Press, Ames

Gillespie TR (2006) Non-invasive assessment of gastro-intestinal parasite infections in free-ranging primates. Int J Primatol 27:1129-1143

Omitolaa OO, Taylor-Robinson AW (2020) Emerging and re-emerging bacterial zoonoses in Nigeria: current preventive measures and future approaches to intervention. Heliyon. https://doi.org/10.1016/.e04095

Igbozuruike UN (1978) The vegetation of Nsukka area. In: Ofomata GEK (ed) Nsukka environment. Fourth Dimension Publishers, Enugu

James-Rugu NN, Iwuala MOE (2002) Ectoparasites of some domestic animals in Jos Plateau. Nigeria Sci Forum 5(1):149-156

Mbaya AW, Aliyu MM, Nwosu CO, Ibrahim UI (2008) Captive wild animals as potential reservoirs of haemo and ectoparasitic infections of man and domestic animals in the arid-region of Northeastern Nigeria. Vet Arch 78:429-440

Mathison BA, Prittb SB (2014) Laboratory identification of arthropod ectoparasites. Clin Microbiol Rev 27:48-67

Mohammed AA, Lawal MD (2014) Prevalence of haemoparasite and ectoparasite of cattle slaughtered at Sokoto abattoir. Sch J Biol Sci 3(2):32-34

Omudua EA, Amuta EU (2007) Parasitology and urban livestock farming in Nigeria: prevalence of ova in faecal and soil samples and animal ectoparasites in Makurdi. Tydskr S Afr Vet Ver 78(1):40-45

Onyenwe IW, Ikpegbu EO (2004) Prevalence of gastrointestinal parasites of Nigerian. Vet J 25:21-25

Ozioko KU, Okoye Cl, Obiezue RN, Agbu R (2018) knowledge, attitudes, and behavioural risk factors regarding zoonotic infections among bushmeat hunters and traders in Nsukka, southeast Nigeria. Epidemiol Health 40:e2018025

Parola R, Paddock CD, Socolovschi C, Labruna MB, Mediannikov O, Kernif T, Abdad YM, Stenos J, Bitam I, Fournier P, Raoult D (2013) Update on tick-borne rickettsioses around the world: A geographic approach. Clin Microbiol Rev 26:657-702

Premaalatha B, Chandrawathani P, Priscilla FX, Farah Haziqah MT, Jamnah O, Zaini CM, Ramlan MA (2017) A survey of endoparasite and ectoparasite infections of wild rats caught in areas of kuala and lumpur, Malaysia. Malays J Vet Res 8(2):29-34

Swai SE, Schoonman L, Daborn C (2010) Knowledge and attitude towards zoonoses among animal health workers and livestock keepers in Arusha and Tanga, Tanzania. Tanzan J Health Res 12(4):282-288

Soulsby EJL (1982) Helminths, arthropods and protozoa of domesticated animals, 7th edn. Bailliere Tindall, London

Sowemimo OA, Asaolu SO (2008) Epidemiology of intestinal helminth parasites of dogs in Ibadan, Nigeria. J Helminthol 82:89-93

Taylor LH, Latham SM, Woolhouse ME (2001) Risk factors for human disease emergence. Philos Trans R Soc Lond B Biol Sci 356:983-989

Tongjura JD, Amuga GA, Ombugadu RJ, Azamu Y, Mafuiya HB (2012) Infesting livestock in three Local Government Areas (LGAS) of Nasarawa State, Nigeria. Sci World J 7(1):15-17

UNN (University of Nigeria, Nsukka) (2013) Nigeria research policy on research involving animal subjects 2013. University of Nigeria, Nsukka, p 25

Urquhart GM, Armour J, Duncan JL, Dunn AM, Jennings FW (1996) Veterinary parasitology, 3rd edn. Blackwell Science Limited, Oxford

Wakelin D (1996) immunity to parasites: how parasitic Infections are controlled, 1 st. Cambridge University Press, London

Walker AR, Bouattour A, Camicas JL, Estrada-pena A, Horak IG, Latif AA, Pegram $R G$, preston PM (2003) Ticks of domestic animals in Africa: a guide to identification of species. http://www.alanrwalker.com/index/guidebooks. Accessed 1st March 2018

Wang LF, Crameri G (2014) Emerging zoonotic viral diseases. Rev Sci Tech Off Int Epiz 33(2):569-581

Webber LM (2015) Ectoparasitic viral zoonoses in the southern African context. J Hum Virol Retrovirol 2(1):1-5

Wei L, Wang X, Wang C, He H (2010) A survey of ectoparasites from wild rodents and Anourosorex squamipes in Sichuan Province, Southwest China. J Ecol Nat Environ 2:160-166

Woolhouse ME, Gowtage-Sequeria S (2005) Host range, emerging, and reemerging pathogens. Emerg Infect Dis 11(12):1842-1847

\section{Publisher's Note}

Springer Nature remains neutral with regard to jurisdictional claims in published maps and institutional affiliations.

\section{Submit your manuscript to a SpringerOpen ${ }^{\circ}$ journal and benefit from:}

- Convenient online submission

- Rigorous peer review

- Open access: articles freely available online

- High visibility within the field

- Retaining the copyright to your article

Submit your next manuscript at $>$ springeropen.com 